\title{
Identification of the aroma compounds in Vitex doniana sweet: free and bound odorants
}

\author{
Ola Lasekan*
}

\begin{abstract}
Background: Most often, the glycosidically-bound aroma compounds are released during industrial processing or pre-treatment of fruits. This usually introduces modification to the aroma notes of such fruits. Therefore, there is the need to understand the contribution of these bound aroma compounds to the overall aroma of a given fruit. In recent years research studies have reported on the free- and bound volatile compounds of several fruits. However, there is no report yet on Vitex doniana sweet.

Results: Results of gas chromatography-mass spectrometry (GC-MS) and gas chromatography-olfactometry (GC-O) of free and glycosidically-bound aroma-active compounds from Vitex doniana sweet revealed a total of 35 compounds in the free fraction, and 28 compounds were in the bound fraction respectively. Whilst the major group of compounds in the free fraction were terpenes, alcohols, and esters, the bound fraction consisted of ketones, alcohols, terpenes and norisoprenoids.

Conclusion: A comparative analysis of the aroma potencies of the free and bound volatile fractions revealed that; free fraction exhibited strong potency for the fruity and floral notes, and the bound fraction produced more of the flowery, caramel-like and cherry-like notes. In addition results of odour activity values showed that ethylbutanoate, $\beta$-damascenone, ethyl-2-methyl propionate, linalool, hexyl acetate and (Z)-rose oxide contributed highly to the sweet prune-like aroma of the fruit.
\end{abstract}

Keywords: Vitex doniana sweet, Free and bound volatile compounds, Odour activity values

\section{Background}

Vitex doniana sweet (Vds) is the edible fruit that belongs to the family Lamiaceae. There are about 250 species in this family [1]. V. doniana sweet is the most abundant and widespread of this genus in the Savannah regions. The fruit is commonly called 'ucha koro', 'oori-nla' and 'mfudu' or 'mfulu' in Swahili. V. doniana sweet is oblong, about $3 \mathrm{~cm}$ long. It is green when immature, and purplish-black on ripening with a starchy black pulp. Each fruit contains one hard conical seed which is about $1.5-2.0 \mathrm{~cm}$ long and $1-1.2 \mathrm{~cm}$ wide. The fruit which tastes like prunes is rich in nutrients including vitamins A $\left(0.27 \mathrm{mg} \cdot 100^{-1} \mathrm{~g}\right.$ DB), B1 (18.33 mg. $\left.100^{-1} \mathrm{~g} \mathrm{DB}\right), \mathrm{B} 2\left(4.80 \mathrm{mg} \cdot 100^{-1} \mathrm{~g} \mathrm{DB}\right)$, B6 (20.45 mg. $\left.100^{-1} \mathrm{~g} \mathrm{DB}\right)$ and C (35.58 mg. $\left.100^{-1} \mathrm{~g} \mathrm{DB}\right)$ respectively [2]. The fruit which is consumed fresh can

\footnotetext{
*Correspondence: olaniny56@gmail.com Department of Food Technology, University Putra Malaysia, 43400 Serdang, Malaysia
}

be made into jam and wine [3]. $V$. doniana sweet has a unique sweet prune-like aroma when ripened. Although, a number of sugars [4], amino acids and minerals [5] have been reported in Vds, however, there is no study yet on the components responsible for the unique sweet prunelike aroma of the Vds. Studies have shown that fruits' aromatic components are either in the free form, or bound to sugar in the form of glycosides [6-8].

Most often, the glycosidically-bound aroma compounds are released during industrial processing or pre-treatment of fruits. This usually introduces modification to the aroma notes of such fruits [9]. Whilst several studies have reported on the free and glycosidically-bound volatiles in fruits such as strawberry [8], mango [10], raspberry [11], lychee [12], blackberry [6], acerola [7] and a host of other fruits, there has been no study on the volatile constituents of Vitex doniana sweet. 
This study aimed at providing an insight into the free and glycosidically-bound aroma compounds of Vitex doniana sweet.

\section{Results and discussion}

The volatile fractions of both free and glycosidically bound $V$. doniana sweet, separated on two columns (DBFFAP and SE-54) of different polarity are shown in Table 1 and Fig. 1. A total of 35 compounds were identified in the free fraction while only 28 compounds were detected in the bound fraction. In general, the aroma compounds identified in both fractions were made up of alcohols (7), aldehydes (2), acids (2), esters (11), terpenes (9), ketones (3), norisoprenoids (7), and a phenol. The most important ones in terms of concentration and the numbers identified in the free fraction were the terpenes (43\%), alcohols (29\%), and esters (25\%). On the other hand, in the bound fraction, the ketones, were the most abundant (29\%) followed by the alcohols (26\%), terpenes $(20 \%)$ and the norisoprenoids (13\%).

In the free fraction of the sweet black plum, the major aroma-active compounds $\left(>300 \mu \mathrm{g} \mathrm{kg}^{-1}\right)$ were linalool, 2-phenylethanol, 3-methyl-but-3-en-1-ol, ethyl cinnamate, ethylbutanoate, hexyl acetate, methyl octanoate, methyl hexanoate, ethyl-2-methylpropionate, geraniol, and $(Z)$-3-hexen-1-ol. These compounds accounted for $88.8 \%$ of the aroma in the free fraction. In addition, most of these compounds were previously reported in several fruits such as lychee, strawberry, cherry and oranges $[8$, 12-14] either in the free or bound form. The identification of significant numbers of fatty acid esters such as methylbutanoate, ethylbutanoate and methyl hexanoate is an indication of the possible contribution of lipid metabolism in the biogenesis of Vds aroma. Volatile esters are produced by virtually all fruit species during ripening. Most volatile esters have flavour characteristics described as fruity [15]. Worthy of note was the high concentration of linalool $\left(5121 \mu \mathrm{g} \mathrm{kg}^{-1}\right)$ in the Vds. This floral-like terpene alcohol which is produced from isopentenyl pyrophosphate via the universal isoprenoid intermediate geranyl pyrophosphate, and membrane-bound enzymes such as linalool synthase [16] has been reported in lychee [17], Coastal Rican guava [18], mangaba fruit [19] and black velvet tamarind [20]. Another compound of interest is the honey-like 2-phenyl ethanol which produced a significant concentration in the free fraction. The odorant is an important flavour compound in the food and cosmetic industries.

The major volatile compounds in the bound fraction of the Vds were; 4-hydroxy- $\beta$-ionol, guaiacol, $y$-jasmolactone, 4-hydroxy-2,5-dimethyl-3(2H)-furanone, acetophenone, linalool and 3-methyl-but-3-en-1-ol (Table 1). In comparison to the free volatile compounds, which were mainly alcohols, esters and terpenes, the bound volatiles profiles included alcohols, ketones, and norisoprenoids. While most of the alcohols detected in the free fraction, were found in the bound form, there were fewer esters identified in the bound form. Only methyl octanoate was detected in both fractions. The reason for this observation is not farfetched because glycosidically bound volatiles are organic compounds in which the aglycone is volatile. This aglycone must be bounded to the sugar via 'glycosidic bond', for which these compounds have to have an $-\mathrm{OH}-,-\mathrm{SH}$, or $-\mathrm{NH}$. Thus aldehydes, esters and terpenes are not able to form glycosidical bonds. Although, similar alcohol profiles were obtained from both free and bound fractions, the concentrations of the alcohols in the bound fraction were significantly $(\mathrm{P}<0.05)$ lower to that of the free fraction. Of interest is the high abundance of 3-methyl-but-3-en-1-ol in both fractions. The presence of this compound in the bound form attested to the fact that it is an important intermediate in various biosynthetic pathways. In addition, significant numbers of odorous norisoprenoids were detected in the bound fraction. Among them were the floral 4-hydroxy- $\beta$-ionol, the spicy 3-oxo- $\alpha$-ionol, 4-oxo- $\beta$-ionol and the flowery $\beta$-damascenone. Most of these compounds have been detected in several fruits such as grape [21], apple [22], raspberry [11] and passion fruit [23]. Also, identified in trace amounts $\left(<10 \mu \mathrm{g} \mathrm{kg}^{-1}\right)$ in the bound fraction were the two isomers (I \& II) of theaspirane.

However, to gain an insight into the contribution of the aroma compounds to the aroma notes of the free and bound fractions, the 36 odorants detected through aroma extract dilution analysis (AEDA) as the key odorants were quantified. The flavour dilution (FD) factors obtained for the key odorants ranged from 2 to 512 (Table 2). Results revealed an array of aroma notes as shown in Table 2 . The seventeen odorants with FD factors $\geq 16$ were further investigated. The results of the quantitation showed that linalool was the predominant compound in both the free $\left(5121 \mu \mathrm{g} \mathrm{kg}^{-1}\right)$ and the bound $\left(506 \mu \mathrm{g} \mathrm{kg}^{-1}\right)$ fractions respectively (Table 3 ). This was followed by 2 -phenyl ethanol $\left(2457 \mu \mathrm{g} \mathrm{kg}^{-1}\right)$ in the free fraction and acetophenone in the bound fraction. However, a comparative analysis of the aroma potencies revealed that the free volatile fraction of the Vds exhibited more potency for the ethyl-2-methylpropionate, $\beta$-damascenone and ethylbutanoate as exemplified by their high odour activity values (OAVs) (Table 3). On the other hand, the bound fraction recorded higher OAVs for $\beta$-damascenone and linalool respectively. Also, the OAVs indicated that hexyl acetate, ethyl-2-methylpropionate, ethylbutanoate, linalool, $\beta$-damacenone and $(Z)$-rose oxide contributed to the sweet prune-like aroma of the Vds. Interestingly, 


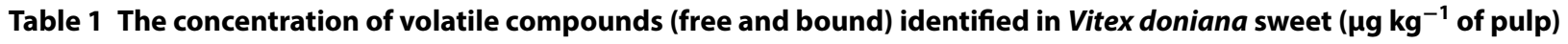

\begin{tabular}{|c|c|c|c|c|}
\hline Compounds $^{1}$ & LR1 & LR2 & Free & Bound \\
\hline \multicolumn{5}{|l|}{ Alcohols } \\
\hline 3-Methyl-but-3-en-1-ol & 1209 & 720 & $1046 \pm 33.0^{\mathrm{a}}$ & $570 \pm 23.6^{b}$ \\
\hline 2/3-Methyl-butanol & 1213 & 738 & $153 \pm 11.4^{\mathrm{a}}$ & $102 \pm 10.6^{b}$ \\
\hline (Z)-3-Hexen-1-ol & 1389 & 858 & $312 \pm 17.2^{\mathrm{a}}$ & $23 \pm 2.0^{b}$ \\
\hline Hexan-1-ol & 1079 & 872 & $60 \pm 3.5^{\mathrm{a}}$ & $33 \pm 1.5^{b}$ \\
\hline 2,6-Dimethylcyclohexanol & 1112 & 979 & $\operatorname{tr}$ & $\operatorname{tr}$ \\
\hline 1-Octen-3-ol & 1451 & 979 & $\operatorname{tr}$ & $\operatorname{tr}$ \\
\hline 2-Phenylethanol & 1911 & 1117 & $2457 \pm 151.0^{\mathrm{a}}$ & $97 \pm 5.9^{b}$ \\
\hline \multicolumn{5}{|l|}{ Aldehydes } \\
\hline 2-Phenylethanal & 1037 & - & $\operatorname{tr}$ & $21 \pm 2.1^{\mathrm{a}}$ \\
\hline Benzaldehyde & 1524 & 1517 & $\operatorname{tr}$ & $35 \pm 3.2^{\mathrm{a}}$ \\
\hline \multicolumn{5}{|l|}{ Acids } \\
\hline 2-Ethyl hexanoic acid & 1129 & - & $\operatorname{tr}$ & $\mathrm{Nd}$ \\
\hline Acetic acid & 1428 & 600 & $18 \pm 2.7^{\mathrm{a}}$ & $19 \pm 0.8^{a}$ \\
\hline \multicolumn{5}{|l|}{ Esters } \\
\hline Ethyl-2-methylpropionate & 961 & 758 & $315 \pm 26.0$ & $\mathrm{Nd}$ \\
\hline Methylbutanoate & 981 & 723 & $205 \pm 16.0^{\mathrm{a}}$ & $\operatorname{tr}$ \\
\hline Ethylbutanoate & 1028 & 803 & $604 \pm 112.0$ & $\mathrm{Nd}$ \\
\hline 1-Pentyl acetate & 1170 & 919 & $37 \pm 4.3$ & $\mathrm{Nd}$ \\
\hline Methyl hexanoate & - & 1000 & $433 \pm 45.1$ & $\mathrm{Nd}$ \\
\hline Butyl butanoate & 1218 & 995 & $65 \pm 5.6$ & $\mathrm{Nd}$ \\
\hline 2-Heptyl acetate & 1259 & 1040 & $\operatorname{tr}$ & $\operatorname{tr}$ \\
\hline Hexyl acetate & 1270 & 1014 & $522 \pm 101.6$ & $\mathrm{Nd}$ \\
\hline (Z)-3-Hexenyl acetate & 1325 & 1007 & $125 \pm 2.5^{\mathrm{a}}$ & $\operatorname{tr}$ \\
\hline Methyl octanoate & - & 1137 & $475 \pm 96.0^{\mathrm{a}}$ & $35 \pm 1.5^{b}$ \\
\hline Ethyl cinnamate & 2167 & 1469 & $715 \pm 117.0$ & $\mathrm{Nd}$ \\
\hline \multicolumn{5}{|l|}{ Terpenes } \\
\hline Limonene & 1185 & 1030 & $127 \pm 9.3$ & $\mathrm{Nd}$ \\
\hline (E)- $\beta$-Ocimene & 1250 & 1156 & $\operatorname{tr}$ & $\mathrm{Nd}$ \\
\hline Borneol & 1253 & 885 & $\operatorname{tr}$ & $\operatorname{tr}$ \\
\hline (Z)-Rose oxide & 1337 & - & $40 \pm 5.0$ & $\mathrm{Nd}$ \\
\hline (E)-a-Bergamotene & 1415 & - & $\operatorname{tr}$ & $\mathrm{Nd}$ \\
\hline Linalool & 1540 & 1103 & $5121 \pm 107.0^{a}$ & $506 \pm 19.4^{b}$ \\
\hline a-Terpineol & 1582 & 1195 & $216 \pm 5.0^{\mathrm{a}}$ & $57 \pm 6.7^{b}$ \\
\hline Geranial & 1715 & 1277 & $114 \pm 4.5$ & $\mathrm{Nd}$ \\
\hline Geraniol & 1840 & - & $341 \pm 13.4^{\mathrm{a}}$ & $79 \pm 8.6^{b}$ \\
\hline \multicolumn{5}{|l|}{ Ketones } \\
\hline Acetophenone & 1067 & - & $42 \pm 6.0^{b}$ & $437 \pm 15.6^{\mathrm{a}}$ \\
\hline 4-Hydroxy-2,5-dimethyl-3(2H)-furanone & 2038 & 1070 & $50 \pm 2.6^{b}$ & $326 \pm 15.0^{\mathrm{a}}$ \\
\hline$\Upsilon$-Jasmolactone & 2176 & - & $\mathrm{Nd}$ & $186 \pm 11.7$ \\
\hline \multicolumn{5}{|l|}{ Phenol } \\
\hline Guaiacol & 1842 & 1089 & $\mathrm{Nd}$ & $231 \pm 14.3$ \\
\hline \multicolumn{5}{|l|}{ Norisoprenoids } \\
\hline Theaspirane isomer I & 1280 & - & $\mathrm{Nd}$ & $\operatorname{tr}$ \\
\hline Theaspirane isomer II & 1308 & - & $\mathrm{Nd}$ & $\operatorname{tr}$ \\
\hline$\beta$-Damascenone & 1801 & 1389 & $\operatorname{tr}$ & $21 \pm 1.7^{\mathrm{a}}$ \\
\hline 4-Hydroxy- $\beta$-ionol & 1601 & - & $\mathrm{Nd}$ & $162 \pm 10$ \\
\hline$\beta$-Ionone & 1933 & 1491 & $260 \pm 12.0^{\mathrm{a}}$ & $\operatorname{tr}^{b}$ \\
\hline 3-Oxo-a-ionol & 1938 & - & $\mathrm{Nd}$ & $100 \pm 12.5$ \\
\hline
\end{tabular}


Table 1 continued

\begin{tabular}{|c|c|c|c|c|}
\hline Compounds ${ }^{1}$ & LR1 & LR2 & Free & Bound \\
\hline \multirow[t]{7}{*}{ 4-Oxo- $\beta$-ionol } & 1943 & - & $\mathrm{Nd}$ & $141 \pm 7.9$ \\
\hline & & Total & $13,900 \mu \mathrm{g} \mathrm{kg}^{-1}$ & $3236 \mu \mathrm{g} \mathrm{kg}^{-1}$ \\
\hline & & Alcohols & $29.1 \%$ & $26.1 \%$ \\
\hline & & Esters & $25.2 \%$ & $1.36 \%$ \\
\hline & & Terpenes & $43 \%$ & $20.1 \%$ \\
\hline & & Ketones & $0.66 \%$ & $29.3 \%$ \\
\hline & & Nop. & $1.91 \%$ & $13.3 \%$ \\
\hline
\end{tabular}

Mean $\pm S D(n=3)$ with different superscript along the same row are significantly different $(P<0.05)$

LR1, DB-FFAP; LR2, SE-54; tr trace amount $\left(<10 \mu \mathrm{g} \mathrm{kg}^{-1}\right)$, Nd not detected, Nop norisoprenoids

$L R$ I linear retention index on column 1, $L R 2$ linear retention index on column 2

${ }^{1}$ Compounds were identified by comparing their retention indices on DB-FFAP and SE-54 columns, their mass spectra, and odour notes were compared with their respective reference odorants' data

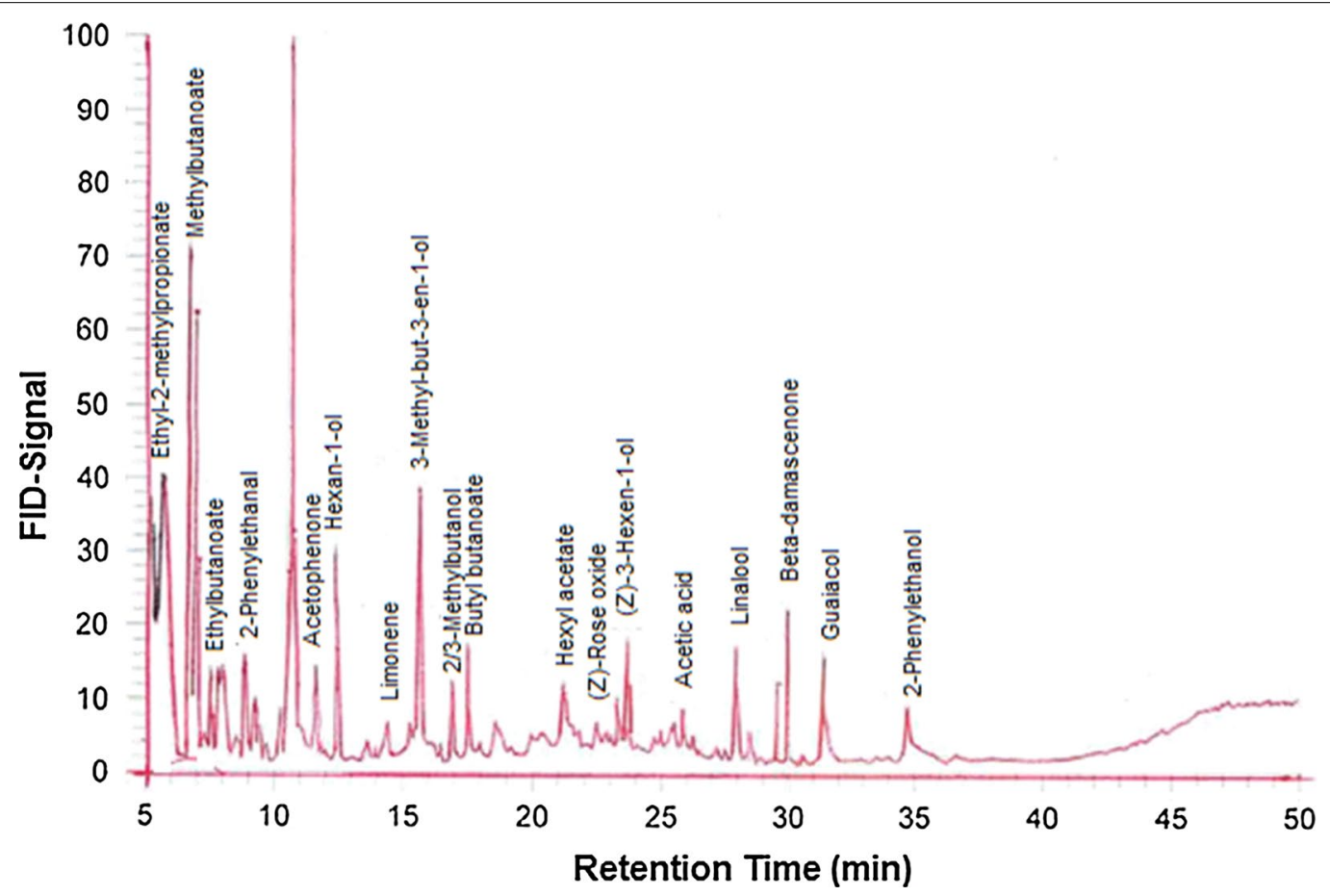

Fig. 1 Characteristic gas chromatogram of solvent extracted sweet Vitex doniana

compounds with high concentration such as 2-phenyl ethanol $\left(2457 \mu \mathrm{g} \mathrm{kg}^{-1}\right)$, geraniol and methyl butanoate gave low OAVs. Therefore, their contribution to the aroma note of the Vds can be assumed to be low.

Sensory evaluation of both bound and free odorants of $V$. doniana sweet revealed distinct aroma characteristics. For instance, while the free fraction was characterised by the flowery and fruity notes, the bound fraction exhibited cherry-like, flowery, and caramel notes (Fig. 2). However to determine which compounds are responsible for the perceived aroma notes, a more detailed analysis on aroma models and omission test will be required.

\section{Conclusion}

The study has revealed for the first time the aroma profiles of the free and glycosidically bound fractions of $V$. doniana sweet. In the free fraction, the predominant compounds were the terpenes, alcohols and esters. The glycosidically bound fraction was composed of ketones, alcohols, terpenes and norisoprenoids. Results of the OAVs revealed 


\begin{tabular}{|c|c|c|c|c|}
\hline No & Compound & Odour impression & DB-FFAP & FD \\
\hline 1 & Ethyl-2-methylpropionate ${ }^{a}$ & Fruity & 961 & 32 \\
\hline 2 & Methylbutanoate ${ }^{a}$ & Fruity & 981 & 128 \\
\hline 3 & Ethylbutanoate $^{a}$ & Banana-like & 1028 & 16 \\
\hline 4 & 2-Phenylethanal ${ }^{\mathrm{b}}$ & Honey-like & 1037 & 4 \\
\hline 5 & Acetophenone $^{\mathrm{a}}$ & Cherry-like & 1067 & 512 \\
\hline 6 & Hexan-1-ol ${ }^{a}$ & Green, blooming & 1079 & 2 \\
\hline 7 & 2,6-Dimethylcyclohexanol ${ }^{c}$ & - & 112 & $\mathrm{Nd}$ \\
\hline 8 & 2-Ethyl hexanoic acida & - & 1129 & $\mathrm{Nd}$ \\
\hline 9 & 1-Pentyl acetate ${ }^{a}$ & Herbal-like & 1170 & 2 \\
\hline 10 & Limonene $^{a}$ & Orange-like & 1185 & 16 \\
\hline 11 & 3-Methylbut-3-en-1-ol ${ }^{a}$ & Slightly apple-like & 1209 & 8 \\
\hline 12 & 2/3-Methylbutanol ${ }^{a}$ & Solvent & 1213 & 4 \\
\hline 13 & Butyl butanoate $^{a}$ & Fruity, pineapple & 1218 & 32 \\
\hline 14 & $(E)-\beta$-Ocimene ${ }^{b}$ & Flowery, blooming & 1250 & 64 \\
\hline 15 & Borneol $^{b}$ & Camphor-like & 1253 & 2 \\
\hline 16 & 2-Heptyl acetate ${ }^{a}$ & Woody, rum-like & 1259 & 2 \\
\hline 17 & Hexyl acetate ${ }^{a}$ & Fruity & 1270 & 16 \\
\hline 18 & (Z)-3-Hexenyl acetate ${ }^{a}$ & Fresh, pear-like & 1337 & 8 \\
\hline 19 & (Z)-Rose oxide ${ }^{\mathrm{a}}$ & Rose-like & 1337 & 16 \\
\hline 20 & (Z)-3-Hexen-1-ol $\left.\right|^{\mathrm{a}}$ & Green & 1389 & 8 \\
\hline 21 & (E)-a-Bergamotene $e^{b}$ & floral & 1415 & 8 \\
\hline 22 & Acetic acid ${ }^{\mathrm{a}}$ & Sweaty & 1428 & 4 \\
\hline 23 & 1-Octen-3-ol $\left.\right|^{\mathrm{a}}$ & Mushroom-like & 1451 & 2 \\
\hline 24 & Benzaldehyde ${ }^{a}$ & Almond-like & 1521 & 16 \\
\hline 25 & Linalool $^{\mathrm{a}}$ & Flowery & 1540 & 16 \\
\hline 26 & $a-$ Terpineol $^{\mathrm{a}}$ & Floral & 1582 & 8 \\
\hline 27 & 4-Hydroxy- $\beta$-ionol ${ }^{a}$ & Floral & 1601 & 16 \\
\hline 28 & Geranial $^{\mathrm{a}}$ & Rose-like & 1715 & 8 \\
\hline 29 & $\beta$-Damascenone ${ }^{a}$ & Flowery & 1801 & 16 \\
\hline 30 & Geraniol $^{\mathrm{a}}$ & Rose-like & 1840 & 16 \\
\hline 31 & Guaiacol $^{\mathrm{a}}$ & Smoky & 1842 & 4 \\
\hline 32 & 2-Phenylethanol ${ }^{\mathrm{a}}$ & Honey-like & 1911 & 16 \\
\hline 33 & $\beta$-lonone ${ }^{a}$ & Floral, violet-like & 1933 & 4 \\
\hline 34 & 3-Oxo-a-ionol ${ }^{c}$ & Spicy & 1938 & 2 \\
\hline 35 & $\begin{array}{l}\text { 4-Hydroxy-2,5-dimethyl- } \\
3(2 \mathrm{H}) \text {-furanone }\end{array}$ & Caramel-like & 2038 & 16 \\
\hline 36 & Ethyl cinnamate ${ }^{a}$ & Flowery, sweet & 2167 & 32 \\
\hline
\end{tabular}

$N d$ not determined, $F D$ flavour dilution

${ }^{a} \mathrm{GC}$ retention and MS data in agreement with that of the reference odorants

${ }^{b} \mathrm{GC}$ retention and MS data in agreement with spectra found in the library

c Tentatively identified by MS matching with library spectra

that while the free volatile fraction of the V. doniana sweet exhibited strong potency for the fruity and floral notes; the bound volatile fraction produced more of flowery, caramel and cherry-like notes. In addition, results have shown that ethylbutanoate, $\beta$-damascenone, ethyl-2-methyl propionate, linalool, hexyl acetate and (Z)-rose oxide contributed highly to the sweet prune-like aroma of $V$. doniana sweet.

\section{Materials and methods}

\section{Fruit material}

Freshly harvested ripe Vitex doniana sweet (purpleblack in colour) (Fig. 3) (300 fruits) grown in Owo, southwest Nigeria, were purchased from a local producer and stored $\left(20{ }^{\circ} \mathrm{C}, 85 \% \mathrm{RH}\right)$. The fruits were $2.8-3.2 \mathrm{~cm}$ in length, $1.2-1.4 \mathrm{~cm}$ in width and contained one hard conical seed each which is about $1.5-2.0 \mathrm{~cm}$ long and 1.0 $1.2 \mathrm{~cm}$ wide. Quartering method [24] was used to select fruits for aroma analysis. At harvest, fruit had $10.5^{\circ}$ brix and a titratable acidity of $0.86 \%$ malic acid equivalent.

\section{Reagents and standards}

Ethanol, methanol and dichloromethane were purchased from Merck (Darmstadt, Germany), while sodium dihydrogen phosphate-1-hydrate, $\mathrm{L}^{-}(+)$-ascorbic acid, and citric acid were obtained from Panreac (Barcelona, Spain). Sodium fluoride and ethyl acetate were purchased from Fluka (Buchs, Switzerland). Almond $\beta$-glucosidase was obtained from Sigma Chemical (St. Louis, MO). Amberlite XAD-2 resins were purchased from SigmaAldrich (Poole, Dorset, UK) and pure water was from a Milli-Q purification system (Millipore, Bedford, MA, USA). An alkane solution $\left(\mathrm{C}_{8}-\mathrm{C}_{24} ; 20 \mathrm{mgL}^{-1}\right.$ dichloromethane) was used to calculate the linear retention index (LRI) for each analyte. Other reagents were of analytical grade.

The following reference chemicals: Acetic acid, methyl butanoate, ethyl-2-methyl propionate, ethyl butanoate, 2-ethylhexanoic acid, 3-methylbutanol, (Z)-3-hexen-1-ol, hexanol, octen-3-ol, benzaldehyde, 3-methyl-but-3-en-1-ol, 2-phenylethanol, 1-pentyl acetate, limonene, 3-methylbut-3-en-1ol, acetophenone, butylbutanoate, $(E)$ - $\beta$-ocimene, 2 -heptyl acetate, hexyl acetate, (Z)-3-hexenyl acetate, (Z)-rose oxide, (Z)3-hexenol, (E)- $\alpha$-bergamotene, 1-octen-3-ol, linalool, $\alpha$-terpineol, 4-hydroxy- $\beta$-ionol, geranial, geraniol, guaiacol, $\beta$-damascenone, $\beta$-ionone, 4-hydroxy-2,5-dimethyl-3(2H)-furanone, ethylcinnamate were from Sigma-Aldrich (St. Louis, MO). Stock standard solutions of $10^{3}$ or $10^{4} \mu \mathrm{g} \mathrm{mL}-1$ of each compound was prepared as described earlier [25].

\section{Fractionation of free aroma compounds of sweet black plum}

Fruit pulp (500 g) was blended with $700 \mathrm{~mL}$ of distilled water. After $30 \mathrm{~s}$, the mixture was centrifuged at $3000 \times g$ and $4{ }^{\circ} \mathrm{C}$ for $15 \mathrm{~min}$. The supernatant was filtered through a bed of Celite. The clear Vds juice $(300 \mathrm{~mL})$ was applied onto an Amberlite XAD-2 adsorbent in a $(30 \times 2 \mathrm{~cm})$ glass column. The column was washed with $250 \mathrm{~mL}$ of deionised water and $200 \mathrm{~mL}$ of n-pentane/ diethyl ether mixture $(1 / 1 \mathrm{v} / \mathrm{v})$. The eluted extract was 
Table 3 A comparative analysis of the aroma potency of compounds with flavour dilution (FD) values $\geq 16$ in Vitex doniana sweet

\begin{tabular}{|c|c|c|c|c|c|c|}
\hline \multirow[t]{2}{*}{ No } & \multirow[t]{2}{*}{ Compounds } & \multicolumn{2}{|c|}{$\begin{array}{l}\text { Conc. }\left(\mu \mathrm{g} \mathrm{kg}^{-1} \text { fresh }\right. \\
\text { fruit) of fractions }\end{array}$} & \multirow[t]{2}{*}{ Threshold ( $\mu \mathrm{g} \mathrm{kg}^{-1}$ of $\mathrm{H}_{2} \mathrm{O}$ ) [ref.] } & \multicolumn{2}{|l|}{ OAVs } \\
\hline & & Free & Bound & & Free & Bound \\
\hline 1 & Ethyl-2-methylpropionate & 315 & $\mathrm{Nd}$ & $0.1[4]$ & 3150 & $\mathrm{Nd}$ \\
\hline 2 & Methylbutanoate & 205 & $<10$ & $28[4]$ & 7 & $<1$ \\
\hline 3 & Ethylbutanoate & 604 & $\mathrm{Nd}$ & $5 \times 10^{-2}[4]$ & 120,800 & $\mathrm{Nd}$ \\
\hline 4 & Acetophenone & 42 & 437 & $65[5]$ & $<1$ & 7 \\
\hline 5 & Limonene & 127 & $\mathrm{Nd}$ & $210[1]$ & $<1$ & $\mathrm{Nd}$ \\
\hline 6 & Butylbutanoate & 65 & $\mathrm{Nd}$ & $100[2]$ & $<1$ & $\mathrm{Nd}$ \\
\hline 7 & (E)-B-Ocimene & $<10$ & $\mathrm{Nd}$ & - & $\mathrm{Nd}$ & $\mathrm{Nd}$ \\
\hline 8 & Hexyl acetate & 522 & $\mathrm{Nd}$ & $2[4]$ & 261 & $\mathrm{Nd}$ \\
\hline 9 & (Z)-Rose oxide & 40 & $\mathrm{Nd}$ & $0.5[1]$ & 80 & $\mathrm{Nd}$ \\
\hline 10 & Benzaldehyde & $<10$ & 35 & $350[5]$ & $<1$ & $<1$ \\
\hline 11 & Linalool & 5121 & 506 & $15[3]$ & 341 & 34 \\
\hline 12 & 4-Hydroxy- $\beta$-ionol & $\mathrm{Nd}$ & 162 & - & $\mathrm{Nd}$ & $\mathrm{Nd}$ \\
\hline 13 & Geraniol & 79 & 341 & $40[4]$ & 2 & 9 \\
\hline 14 & $\beta$-Damascenone & $<10$ & 26 & $2 \times 10^{-3}[4]$ & 5000 & 10,500 \\
\hline 15 & 2-Phenylethanol & 2457 & 97 & $1000[4]$ & 3 & $<1$ \\
\hline 16 & 4-Hydroxy-2,5-dimethyl-3(2H)-furanone & 50 & 326 & $40[4]$ & 1 & 8 \\
\hline 17 & Ethyl cinnamate & 715 & $\mathrm{Nd}$ & - & $\mathrm{Nd}$ & $\mathrm{Nd}$ \\
\hline
\end{tabular}

Nd not detected, OAVs odour activity values

[1] Maarse [29], [2] Takeoka et al. [30], [3] Lasekan \& Ng [20], [4] Rychlik et al. [31], [5] Buttery et al. [32]

$\mathrm{OAVs}$, calculated by dividing concentration with threshold value in water

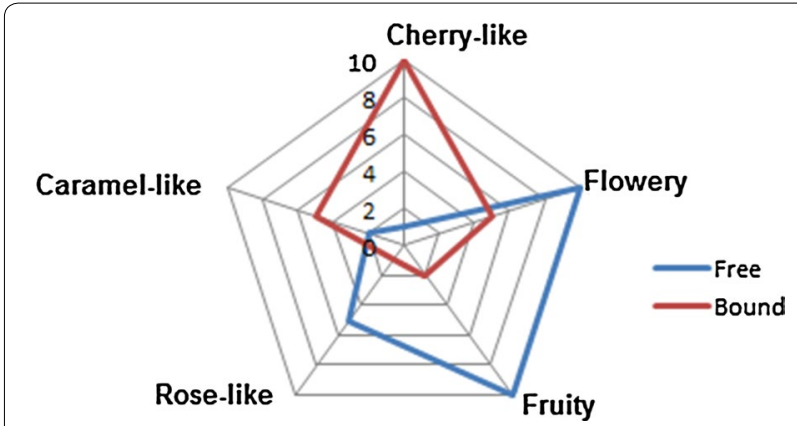

Fig. 2 Comparative aroma profiles of bound and free compounds in Vitex doniana sweet

dried over anhydrous sodium sulphate and concentrated to $1 \mathrm{~mL}$ [26]. The concentrated extract (i.e. free fraction of the sweet black plum) was used for the GC-MS and $\mathrm{GC}-\mathrm{O}$ analyses. The experiment was carried out in triplicate.

\section{Bound aroma compounds of the $V$. doniana sweet}

After the free fraction was obtained from the Amberlite XAD-2 glass column, the glycosidic extract adsorbed on the column was collected by washing it with $250 \mathrm{~mL}$ of methanol. The obtained extract was dried over

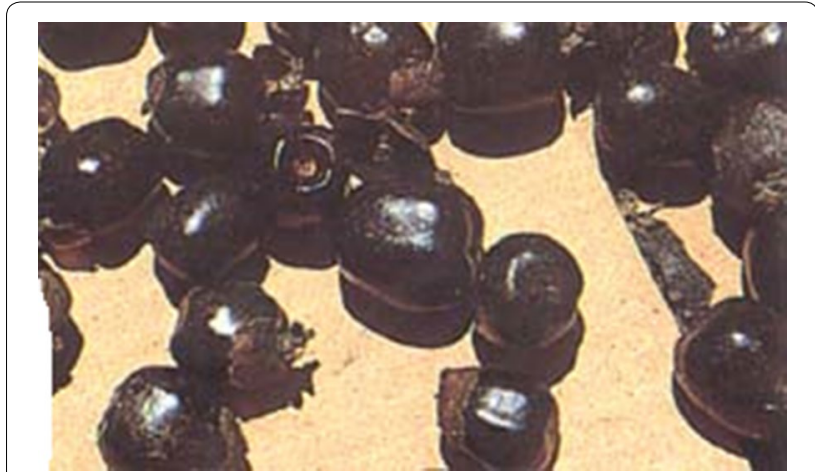

Fig. 3 Ripened Vitex doniana sweet

anhydrous sodium sulphate and similarly concentrated as the free fraction. The concentrated bound fraction was re-dissolved in $100 \mathrm{~mL}$ of phosphate-citrate buffer $(0.2 \mathrm{M}, \mathrm{pH} 5.0)$ and washed $(2 \times)$ with $45 \mathrm{~mL}$ of $\mathrm{n}$-pentane/diethyl ether $(1 / 1, \mathrm{v} / \mathrm{v})$ to remove any free fraction. One mililiter of an almond $\beta$-glucosidase solution $\left(5\right.$ unit $\mathrm{mg}^{-1}$ solid, concentration of 1 unit $\mathrm{mL}^{-1}$ buffer) was added to the glycosidic extract and incubated overnight at $37{ }^{\circ} \mathrm{C}$ [27]. The liberated aglycones were extracted with $30 \mathrm{~mL}$ of $\mathrm{n}$-pentane/diethyl ether 
$(1 / 1, v / v)(2 \times)$. The combined extracts were dried over anhydrous sodium sulphate, filtered and concentrated as described earlier [26]. The concentrated extract was used for the GC-MS analysis and the experiment was carried out in triplicate.

\section{GC-MS and GC-FID analyses}

A Shimadzu (Kyoto, Japan) QP-5050A GC-MS equipped with a GC-17 A Ver.3, a flame ionization detector (FID) and fitted differently with columns DB-FFAP and SE-54 (each, $30 \mathrm{~m} \times 0.32 \mathrm{~mm}$ i.d., film thickness $0.25 \mu \mathrm{m}$; Scientific Instrument Services, Inc., Ringoes, NJ) was employed. The gas chromatographic and mass spectrometric conditions were the same as described previously by Lasekan \& Ng, [20]. The HP Chemstation Software was employed for the data acquisition and mass spectra were identified using the NIST/NB575K database.

\section{Gas chromatography-olfactometry}

A Trace Ultra 1300 gas chromatograph (Thermo Scientific, Waltham, MA, USA) fitted with a DB-FFAP column $(30 \mathrm{~m} \times 0.32 \mathrm{~mm}$ i.d., film thickness, $0.25 \mu \mathrm{m}$, Scientific Instrument Services, Inc., Ringoes, NJ) and an ODP 3 olfactory Detector Port (Gerstel, Mulheim, Germany), with additional supply of humidified purge air, was operated as earlier reported by Lasekan et al. [25]. The split ratio between the sniffing port and the FID detector was 1:1. Two replicate samples were sniffed by three trained panellists who presented normalised responses, reproducibility and agreement with one another. The $\mathrm{GC}-\mathrm{O}$ analysis was divided into three parts of $20 \mathrm{~min}$ and each panellist participated in the sniffing. An aroma note is valid only when the three panellists were able to detect the odour note.

\section{Identification and quantification}

The linear retention indices were calculated according to Kovats method using a mixture of normal paraffin $\mathrm{C}_{6}-\mathrm{C}_{28}$ as external references. The identification of volatiles was carried out by comparing their retention indices, mass spectra data and odour notes with those of the reference odorants, literature data or with the data bank (NIST/NB575K). Quantitative data were obtained by relating the peak area of each odorant to that of the corresponding external standard and were expressed as $\mu \mathrm{g} \mathrm{kg}{ }^{-1}$.

\section{Aroma extracts dilution analysis (AEDA)}

The extracts of the free and bound fractions were diluted step wise twofold with dichloromethane by volume to obtain dilutions of 1:2, 1:4, 1:8, and 1:16 and so on. Each obtained dilution was injected into the GC-O. The highest dilution in which an aroma compound was observed is referred to as the FD factor of that compound [28].

\section{Aroma profile determination}

Fresh Vds (40 g) were placed inside glass containers $(7 \mathrm{~cm} \times 3.5 \mathrm{~cm})$ and were orthonasally analysed as described earlier [20]. Reference odorants used were: Acetophenone (cherry-like), linalool (Flowery), (Z)-rose oxide (rose-like), 4-hydroxy-2,5-dimethyl-3(2H)-furanone (caramel-like) and hexyl acetate (fruity). Panellists rated the intensities of each descriptor on an unstructured scale from 0 to 10 , where $0=$ not detectable, $5=$ weak, and $10=$ strong. Final results were presented in a web plot.

\section{Statistical analysis}

Statistical analyses were carried out with SPSS version 16.0 Windows (SPSS Inc., Chicago, IL). Significance of differences between means was tested by one-way analysis of variance (ANOVA). Results were expressed as mean $\pm \mathrm{SD}$ (standard deviation) of triplicate analyses.

\section{Acknowledgements}

The author is grateful for the extensive financial support of the Fundamental Research Scheme (No. 5524558) at the University Putra Malaysia.

\section{Competing interests}

The author declares that he has no competing interests.

Received: 18 July 2016 Accepted: 14 February 2017

Published online: 23 February 2017

\section{References}

1. Padamalatha K, Jayaram K, Rajau NL, Prasad MNV, Arora R (2009) Ethnopharmacology and biotechnological significance of vitex. Global Sci. 3:6-14

2. Vunchi MA, Umar AN, King MA, Liman AA, Jeremiah G, Aigbe CO (2011) Proximate, vitamins and mineral composition of Vitex doniana fruit pulp. Nig J Basic Appl Sci. 19:97-101

3. Nnajiofor RO (2003) Fermentation of black plum (Vitex doniana) juice for the production of wine. Fruits 58:373-389

4. Agbede JO, Ibitoye AA (2007) Chemical composition of black plum (Vitex doniana): an under-utilized fruit. J Food Agric Environ 5:95-96

5. Glew RH, Vanderjagt DJ, Lockett C, Grivetti LE, Smith GC, Pastuszyn A, Milson M (1997) Amino acid, fatty acid, and mineral composition of 24 indigenous plants of Burkina Faso. J Food Compos Anal 10:205-217

6. Humpf HU, Schreier P (1991) Bound aroma compounds from the fruit and the leaves of blackberry (Rubus lacimiata L). J Agric Food Chem 39:1830-1832

7. Boulanger R, Crouzet J (2001) Identification of aroma components of acerola (Malphigia glabra L): free and bound flavour compounds. Food Chem 74:209-216

8. Ubeda C, San-Juan F, Concejero B, Callejon RM, Troncoso AM, Morales ML, Ferreira V, Hernandez-Orte I (2012) Glycosidically bound aroma compounds and impact odorants of four strawberry varieties. J Agric Food Chem 60:6095-6102

9. Kobayoshi A, Kubota K, Wang D (2000) Qualitative and quantitative analyses of glucosides as aroma precursors during black tea manufacturing process. In: Schieberle P, Engel KH (eds) Frontiers of flavour Science. Deutsche Forschungsanstalt fur Lebensmittelchemie, Garching, pp 452-456

10. Sakho M, Chassagne D, Crouzet J (1997) African mango glycosidically bound volatile compounds. J Agric Food Chem 45:883-888 
11. Pabst A, Barron D, Etievant P, Schreier P (1991) Studies on the enzymic hydrolysis of bound aroma constituents from raspberry fruit pulp. J Agric Food Chem 39:173-175

12. Chyau CC, Ko PT, Chang CH, Mau JL (2003) Free and glycosidically bound aroma compounds in lychee (L. Chinensis Sonn). Food Chem 80:387-392

13. Fan G, Qiao Y, Yao X, Mo D, Wang K, Pan S (2009) Free and bound volatile compounds in juice and peel of Jincheng oranges. Eur Food Res Technol 229:571-578

14. Wen YQ, He F, Zhu BQ, Lan YB, Pan QH, Li CY, Reeves MJ, Wang J (2014) Free and glycosidically bound aroma compounds in cherry. Food Chem 152:29-36

15. Burdock GA (2005) Fenaroli's handbook of flavour ingredients, 5th edn. CRC Press, Boca Raton

16. Lasekan O (2016) Flavour and aroma compounds of some exotic tropical fruits and berries: biosynthetic pathways and metabolism. In: Pareek S (ed) Postharvest ripening physiology of crops. CRC Press, Boca Raton, pp 553-579

17. Ong PK, Acree TE (1998) Gas chromatography/olfactory analysis of lychee (Litchi chinesis Sonn.). J Agric Food Chem 46:2282-2286

18. Pino JA, Marbot R, Vázquez C (2002) Characterization of volatiles in Costa Rican guava [Psidium friedrichsthalianum (Berg) Niedenzu] fruit. J Agric Food Chem 50:6023-6026

19. Sampaio TS, Nogueira PCL (2006) Volatile components of mangaba fruit (Hancornia speciosa Gomes) at three stages of maturity. Food Chem 95:606-610

20. Lasekan O, Ng SS (2015) Key volatile aroma compounds of three black velvet-tamarind (Dialium) fruit species. Food Chem 168:561-565

21. Skouroumounis GK, Massy-Westropp RA, Sefton MA, Williams PJ (1992) Precursors of damascenone in fruit juices. Tetrahedron Lett 33:3533-3536

22. Schwab W, Schreier P (1990) Glycosidic conjugates of aliphatic alcohols from apple fruit (Malus sylvestris Mill cult. Jonathan). J Agric Food Chem 1990(38):757-763
23. Chassagne D, Crouzet J, Bayonove C, Brillouet JM, Baumes R (1996) 6-0-a-L-arabinopyranosyl- $\beta$-glucopyranosides as aroma precursors from passion fruit. Phytochemistry 41:1497-1500

24. Horwitz W (1988) Sampling and preservation of sample for chemical examination. J Assoc Anal Chem. 71:224-247

25. Lasekan O, Khatib A, Juhari H, Patiram P, Lasekan A (2013) Headspace solid-phase microextraction gas chromatography-mass spectrometry determination of volatile compounds in different varieties of African star apple fruit (Chrysophillum albidum). Food Chem 141:2089-2097

26. Lasekan O, Buettner A, Christlbauer M (2007) Investigation of important odorants of palm wine (Elaeis guineensis). Food Chem 105:15-23

27. Groyne J, Lognay G, Marlier M (1999) Accumulation of glycosidically bound compounds in Fragaria $x$ ananassa cv. Elsanta fruits at various developmental stages. Biotechnol Agr Soc Environ 3:5-9

28. Schieberle P (1995) Quantitation of important roast-smelling odorants in popcorn by stable isotope dilution assays and model studies on flavour formation during popping. J Agric Food Chem 43:2442-2448

29. Maarse H (1991) Number and level of volatile compounds in fruits. In: Maarse $\mathrm{H}$ (ed) Volatile compounds in foods and beverages. CRC Press, Boca Raton, pp 27-30

30. Takeoka GR, Flath RA, Mon TR, Teranishi R, Guentert M (1990) Volatile constituents of apricot (Prunus armeniaca). J Agric Food Chem 38:471-477

31. Rychik M, Schieberle P, Grosch W (1998) Compilation of odour thresholds, odour qualities and retention indices of key food odorants. Deutsche Forschungsanstalt fur Lebensmittelchemie, Garching

32. Buttery RG, Turnbaugh JC, Ling LC (1988) Contribution of volatiles to rice aroma. J Agric Food Chem 36:1006-1009

\section{Submit your manuscript to a SpringerOpen ${ }^{\odot}$ journal and benefit from:}

- Convenient online submission

- Rigorous peer review

- Immediate publication on acceptance

- Open access: articles freely available online

- High visibility within the field

- Retaining the copyright to your article

Submit your next manuscript at springeropen.com 